\title{
Patronage or Participation? Community-based Natural Resource Management Reform in Sub-Saharan Africa
}

\section{Fred Nelson and Arun Agrawal}

\begin{abstract}
This article examines the institutional factors that account for the outcome of efforts to decentralize control over natural resources to local communities. It focuses on the political nature of institutional processes associated with decentralization in sub-Saharan Africa through a comparative analysis of wildlife management reforms in seven east and southern African countries. Institutional reforms are largely dependent on state authorities' patronage interests, which in turn are shaped by the relative economic value of wildlife, the degree of central control over commercial utilization, and the accountability of governance institutions. Our findings have a range of practical implications for the design of CBNRM initiatives and institutional reform strategies.
\end{abstract}

\section{INTRODUCTION}

During the past twenty years community-based natural resource management (CBNRM) has been adopted widely in sub-Saharan Africa as a mechanism to combine rural development and conservation efforts (Fabricius et al., 2004; Hulme and Murphree, 2001). The premise underlying CBNRM reforms is that sustainable management is most likely where local users are able to manage and extract benefits from natural resources (Jones and Murphree, 2004; Kull, 2002; see also Ostrom, 1990). CBNRM efforts are a response to the reality that many cases of rural resource degradation occur because centralized management regimes in African states are often de facto open access regimes and that vesting local users with rights to manage, use or own resources is therefore a key corrective.

CBNRM's wide adoption in the context of decentralization is likely a result of multiple factors, including the growth of scholarship on common property and in political ecology during the past twenty years; the broader tenets of

We acknowledge financial support for the work in this article from the Ford Foundation, the John D. and Catherine T. MacArthur Foundation and the Bradley Fund for the Environment. Earlier drafts of this paper benefited greatly from comments provided by Simon Anstey, Clark Gibson, Jesse Ribot, Steven Yaffee and two anonymous referees.

Development and Change 39(4): 557-585 (2008). C Institute of Social Studies 2008. Published by Blackwell Publishing, 9600 Garsington Road, Oxford OX4 2DQ, UK and 350 Main St., Malden, MA 02148, USA 
the neo-liberal orthodoxy of market-based incentives, property rights, and decentralization; donor interests in achieving synergies between rural development and biodiversity conservation; and the intersection between local demands for greater control over resources and political decision makers' interests in reducing expenditures (Agrawal et al., 2008; Batterbury and Fernando, 2006; Brosius et al., 2005). Irrespective of its diverse social, political, and theoretical origins, CBNRM is fundamentally premised on institutional reforms that decentralize authority over - and benefits from land and natural resources to local actors. In the absence of such reforms, the incentives for local groups of people to collectively invest in natural resource management are unlikely to exist or emerge. The lack of downwardly accountable decentralization or devolution is increasingly recognized as the principal barrier to CBNRM in sub-Saharan Africa (Child and DalalClayton, 2004; Jones and Murphree, 2004; Murphree, 2004; Shackleton et al., 2002).

Ribot (2004: 3) similarly concludes that the prevalent failure to transfer sufficient decision-making powers to the local level 'turn most decentralization reforms into charades' (see also Ribot et al., 2006). Such institutional barriers are by no means restricted to natural resource management reforms. They characterize administrative decentralization processes more generally (for example Olowu, 2003). As one recent review concludes, 'the central state does not relinquish enough control to local people eager to receive it. This is the fundamental challenge to decentralization reforms' (Batterbury and Fernando, 2006: 1861).

These outcomes of CBNRM and decentralization are strongly conditioned by the institutional incentives facing political decision-makers. Valuable natural resources create incentives for central actors to retain control over them, even when these actors sometimes claim to decentralize control. Wildlife is a valuable patronage resource in the context of Africa's neo-patrimonial governance institutions (Gibson, 1999). The common outcome for CBNRM reform efforts in contexts of high resource value and low institutional accountability is that such reforms often occur only on paper, and power to allocate resources continues to be monopolized by central actors with neopatrimonial motivations (Ribot et al., 2006).

The continued use of reformist narratives set against the reality of persistent centralized resource control has led to a growing sense among scholars and practitioners that CBNRM is failing to deliver. Jones and Murphree (2004: 86) observe that CBNRM 'performance has rarely approximated promise, and in some cases has been abysmal'. Blaikie (2006: 1947) states that 'CBNRM programs in central and southern Africa have substantively failed to deliver ... to both communities and the environment'. Neumann (1997), an early writer on the subject, suggested that many efforts to involve local peoples have only succeeded in reproducing earlier more coercive forms of conservation. One result of empirical failures and critical narratives is a backlash against CBNRM (see Hutton et al., 2005) that threatens 
to prematurely undermine support for these strategies before they have ever been effectively implemented (Ribot, 2004). It is in this context that our article explores the institutional aspects of CBNRM in sub-Saharan Africa in an effort to understand and explain the motivations and outcomes of reform efforts.

\section{STRUCTURE, METHODS AND SCOPE}

Our analysis focuses on key institutional and political variables that drive or impede the adoption of reforms. Our approach is comparative, starting with a description and analysis of community-based wildlife management in Tanzania. As one of the region's more natural resource-rich countries particularly in terms of wildlife, and as the site of long-running external support to CBNRM, Tanzania provides a useful entry point for examining some of the institutional challenges facing CBNRM efforts. We follow the Tanzanian case with six brief country reviews from east and southern Africa: Botswana, Kenya, Mozambique, Namibia, Zambia and Zimbabwe. The selection of these additional countries is based on their collectively constituting the main wildlife-rich nations in the region. ${ }^{1}$

The country reviews focus on patterns of commercial wildlife utilization, the extent of devolution or democratic decentralization in the reforms carried out, and the key actors involved in the reform processes. We then analyse all seven cases in terms of the relative roles of central patronage interests and incentives, the influence of foreign donors, and the influence of popular demands for reform. Our goal is to identify the key explanatory variables underlying regional CBNRM outcomes. Our analysis thus does not directly examine whether devolution and CBNRM reforms lead to improved measures of resource condition, but rather focuses on the institutional dimensions of reform outcomes. This comparative approach highlights the paramount role of central actors' incentives, and the relatively lower importance of local participation and advocacy efforts in explaining reform outcomes in the selected countries. Our analysis of institutional factors raises systematic questions about the nature of present day and future reforms; it also suggests some clear lessons about the conditions under which continuing efforts to address natural resource management and governance in the region may turn out to be more successful.

\section{CBNRM IN TANZANIA'S WILDLIFE SECTOR}

The history of wildlife management in Tanzania is characterized by the gradual consolidation of increasingly centralized control over wildlife resources

1. For example, these six countries plus Tanzania collectively hold about 83 per cent of Africa's total known and probable elephant population (Blanc et al., 2007). 
since the beginning of the colonial era (Nelson et al., 2007; Neumann, 1998). Wildlife management practices have been based on two fundamental strategies: legally proscribing or restricting wildlife uses and establishing national parks and game reserves to protect animal populations (Nelson et al., 2007). The post-independence era has witnessed continued expansion of central control over wildlife and further elimination of local use rights, in part linked to Tanzania's broader socialist policies of rural transformation and state economic control during the 1960s and 1970s (Hyden, 1980). As a result, Tanzania has established one of the world's largest protected area networks, with nearly 30 per cent of its land set aside in exclusive parks and reserves (Brockington, 2006).

Tanzania's wildlife constitutes an increasingly valuable economic resource. Tanzania has been a leading destination for European and American trophy hunters since the late nineteenth century. A system of tourist hunting concessions based on individual animal quotas was established in the 1960s. The Wildlife Division in the Ministry of Natural Resources and Tourism has had control over the administration of the system since 1988 (Barnett and Patterson, 2006). With greater economic openness to private and foreign capital from the late 1980s, Tanzania's sport hunting industry has grown rapidly (Lindsey et al., 2007); see Figure 1. About half of all hunting concessions are in Game Reserves and half of them outside protected areas on community lands ${ }^{2}$ (Barnett and Patterson, 2006). Local people do not, however, have any formal role in administering the hunting concessions on their lands and all revenues flow to the state, with some being passed back to the districts where hunting takes place.

The Wildlife Division earned an estimated \$ 10.5 million in direct payments from hunting in 2001, up from about \$ 1.5 million in 1989 (Baldus and Cauldwell, 2004; Barnett and Patterson, 2006). Commercial hunting is thus the Wildlife Division's principal form of revenue and its primary management mandate. ${ }^{3}$ Hunting concessions are allocated administratively with little or no public participation or accountability, although an advisory committee was formed in 1996 to make recommendations on concessions. There are substantial opportunities for rent seeking in the wildlife industry as a result of the high level of administrative discretion. These opportunities have increased with the growth of the industry over the past fifteen years (Baldus and Cauldwell, 2004; Barnett and Patterson, 2006; Nshala, 1999).

2. For purposes of hunting administration, community lands are termed either Game Controlled Areas or Open Areas. While Game Controlled Areas are sometimes included in Tanzania's protected area estate, they are settled areas where land uses are determined by local residents and state wildlife authorities maintain no permanent physical presence.

3. Tanzania's national parks are not managed by the Wildlife Division but by a semiautonomous parastatal, Tanzania National Parks; these parks are the focus of Tanzania's growing tourism industry. Resources inside national parks are managed by TANAPA, while all wildlife outside parks, which includes wildlife in Game Reserves as well as on unprotected community or private lands, is under the Wildlife Division's jurisdiction. 
Figure 1. Growth in Total Revenue from Tanzania's Tourist Hunting Industry, 1989-2001

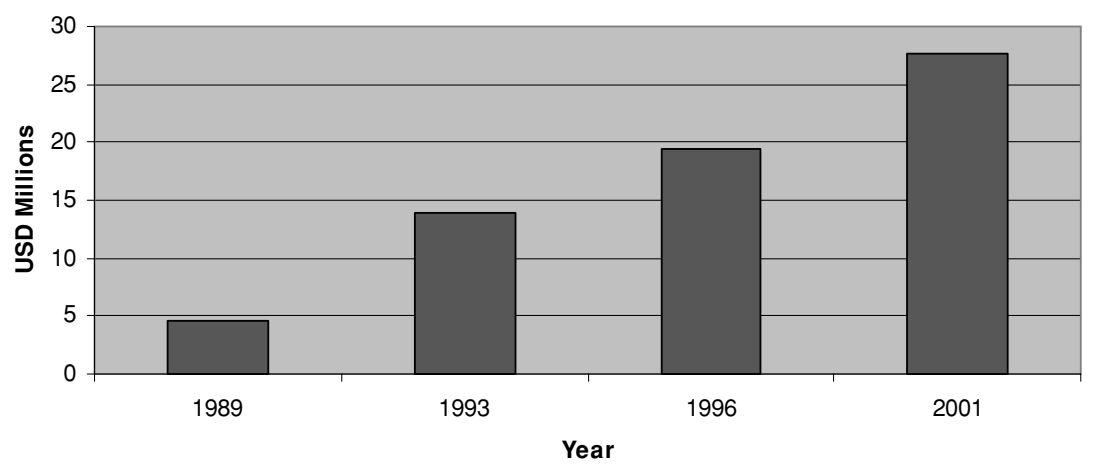

Source: Baldus and Cauldwell (2004)

One review carried out in the 1990s found little correlation between operator performance and the retention of hunting concessions, with corruption identified as the principal factor influencing block retention (Overton, 1998). In the absence of transparent mechanisms such as public auctions or open tender processes, hunting concession prices have been kept artificially low, further enhancing rent-seeking opportunities (Baldus and Cauldwell, 2004).

The expansion of Tanzania's wildlife industry during the 1990s occurred alongside trends of wildlife depletion in many rural areas, symptomatic of the failure of the country's strictly centralized wildlife management institutions (WSRTF, 1995). Under uniform state ownership, local people have few incentives to value wildlife or invest in conservation. Instead, they remained saddled with the costs of living with wildlife, while the benefits of the resource were captured by the state and private sector. A Ministerial task force convened in the early 1990s concluded, 'there is no effective means now in place for conserving biological resources outside PA [protected area] networks' (WSRTF, 1995: 3).

In 1998, in response to these challenges and broader economic and political reforms in the country, the government released a new wildlife policy calling for devolution of wildlife management rights and responsibilities to the local level. The mechanism for carrying out this reform is described in the policy as a new entity called Wildlife Management Areas (WMAs), set aside voluntarily on community lands "where local people will have full mandate of managing and benefiting from their conservation efforts' (MNRT, 1998: 31). The policy's assumption was that communities would have new incentives to support conservation and prevent unsustainable exploitation of wildlife if they earned economic benefits from wildlife (MNRT, 1998; Songorwa, 1999). 
In order to create community-managed WMAs, the Wildlife Division produced detailed regulations delineating the procedures for WMA formation (MNRT, 2002). However, the rights over wildlife granted to the communities under this WMA framework are limited, restricting usufruct rights over wildlife to three-year terms, failing to clarify the proportion of revenue from wildlife in WMAs that locals will be able to capture, and maintaining centralized control over hunting concessions (Igoe and Croucher, 2007). Communities must fulfil a dozen conditions before a WMA can be gazetted (Goldman, 2003). As a result, there has been only limited progress in realizing the 1998 wildlife policy's objectives with regards to increasing the role of local communities in managing and benefiting from wildlife (Nelson et al., 2007). Conflicts between local communities and external actors over the implementation of WMAs are commonplace (Igoe and Croucher, 2007). Wildlife populations at the ecosystem scale have continued to decline across Tanzania (Stoner et al., 2007).

After nearly two decades of reform efforts, Tanzania's wildlife sector is thus emblematic of the challenges characterizing many CBNRM initiatives. Although government policies call for significant institutional reform, a number of factors have prevented devolution in practice. The state has continued the expansion of protected areas (see Brockington, 2006) and also attempted to extend authority over local community-based tourism ventures that realize income at the local level but operate outside the central jurisdiction (Nelson et al., 2007).

The trajectory of institutional change in Tanzanian wildlife management is best explained by the interests and actions of state wildlife authorities who control and shape policy and legislative changes. Tanzania's public institutions are characterized by low levels of transparency and accountability (URT, 2005). During the past twenty years of neo-liberal policy reforms, public officials have become more involved in using their positions to pursue private accumulative interests (Kelsall, 2002). For governing elites, maintaining control over valuable productive resources is central to the construction of patronage networks and thus reinforcement of their privileged positions (van de Walle, 2001). As wildlife's value has increased with the growth of the tourist hunting industry since the late 1980s, its value for patronage has also expanded. A critical aspect of this high patronage value is the wide discretionary powers that wildlife authorities possess over the centralized hunting industry, and the dependence of that industry on community lands. These factors create substantial bureaucratic disincentives to the implementation of the reforms articulated in the 1998 policy.

Wildlife authorities do, however, possess additional, potentially countervailing interests. Community-based wildlife sector reforms have been largely motivated and supported by foreign donors and international conservation organizations (Baldus et al., 2003; Goldman, 2003; Songorwa, 1999). Those groups possess financial resources valued by state authorities. These resources are contingent on implementation of the reform agenda 
- at least to some degree. Wildlife authorities also face pressures to accommodate local economic concerns and aspirations with respect to the distribution of wildlife's costs and benefits, aspirations that are increasingly being articulated by parliamentary representatives. Finally, ministerial officials are under some pressure from within the executive branch to ensure that wildlife population declines are addressed because of the economic importance of wildlife for the tourism industry.

It is clear that patronage and rent-seeking benefits to decision makers play a paramount role in prompting a high degree of central control over wildlife. These benefits are amplified by relatively low levels of public transparency and accountability and the centralized and high commercial value of Tanzania's wildlife. Other actors, including both local communities and foreign donors, have only limited ability to influence the thoroughness with which institutional reforms are implemented, even if donors can help prompt the launching of reforms. The marginality of local communities from these processes throughout their duration over the past two decades has been notable - local populations have played a small role at best in policy formulation or setting the wildlife sector reform agenda (see also Sunseri, 2005). Although local communities are vocal and active in their resistance to many aspects of wildlife conservation policy in Tanzania (Igoe, 2004), most of the continuing dialogue over wildlife sector reforms occurs mainly amongst government personnel and their donor agency and conservation NGO supporters. This stands in contrast, for example, to Tanzania's land tenure reforms that were carried out during the mid-1990s, and where civic organizations and grassroots networks of activists mobilized popular campaigns and played a significant role in influencing outcomes (Sundet, 1997).

As for the apparent inability of donors to influence reform outcomes, it is notable that Tanzanian wildlife authorities have reaped large benefits from donor support during the past fifteen years without surrendering significant control over wildlife. Donors and foreign conservation organizations have invested millions of dollars in the wildlife sector, largely motivated and rationalized through the economic and environmental logic of CBNRM. ${ }^{4}$ These investments have not led to the desired outcomes, and donors have generally been frustrated by their inability to spur reform. It is ironic that one constraint CBNRM in Tanzania's wildlife sector has not faced is the absence of financial support; rather, the resources invested have not addressed the underlying institutional problems facing wildlife management.

Our description and analysis of the outcome of Tanzania's wildlife sector reforms points to several potential generalizations about the factors that influence CBNRM reform outcomes. First, the Tanzanian experience suggests that where the value of wildlife on community lands is high but is captured by central actors through established systems of commercial exploitation

4. In this context, see Brockington's (2006) discussion of an 'environmental conservation complex'. 
(for example, tourist hunting concessions), devolutionary reforms are less likely to occur. Second, bureaucratic incentives are also influenced by the broader governance context, particularly the level of transparency and accountability in public institutions. Third, foreign donors may play a key role in initiating reform processes but ultimately have little leverage in forcing durable institutional changes. Fourth, popular political forces may have a role in CBNRM outcomes, with devolutionary reform more likely where local participation and activism are a prominent part of policy processes, and less likely where such pressures are absent. Although Tanzanian communities appear to have had little influence over reforms and are in many respects politically disempowered as a result of high levels of concentrated central authority, local actors and interests can modify the impacts of strategies employed by state actors even in contexts where local power seems limited (Boone, 2003; Scott, 1985). We proceed to analyse the relevance of these factors - the patronage incentives of state decision makers, and the roles of donors and local communities - by examining the experiences of a larger set of African countries with CBNRM reforms.

\section{CBNRM REFORM IN EAST AND SOUTHERN AFRICA}

Reforms proposing to transfer authority over wildlife to the local level have been a widespread feature of the institutional landscape in east and southern Africa's wildlife-rich nations (Hulme and Murphree, 2001). We focus on six country case studies to examine the factors that account for variations in the extent to which local institutions exercise authority over wildlife management. The key actors and interests involved in reform processes and outcomes are briefly examined (cf. Agrawal and Ribot, 1999). We pay particular attention to the way wildlife is valued by central actors as a patronage resource, and the degree of influence of donors and local communities in shaping reform processes.

\section{Namibia}

Namibia's wildlife management approach diverged from the centralized colonial model in 1968 and later in 1975 when legal reforms granted private landowners conditional ownership rights ${ }^{5}$ to wildlife on their lands (Jones and Murphree, 2001). This measure applied only to freehold lands owned by whites in a country which was then administered by South Africa. ${ }^{6}$ In the two decades following these reforms, wildlife on private lands increased

5. The main conditionality was that the landowner erect a game-proof fence around his property.

6. Such freehold lands comprise 41 per cent of Namibia's total land area. 
by about 80 per cent as ranchers invested in wild game production for meat and hunting (Barnes and de Jager, 1995).

In 1996, Namibia amended its wildlife laws to provide for the creation of community conservancies. Community conservancies grant communities broad usufruct rights over common game species and conditional rights over rarer species. Since 1997, over forty conservancies have been established, with about 10 per cent of Namibia's total land area now falling under their jurisdiction (NACSO, 2004). It is true that the rights granted to communities are conditional and fall short of full ownership of wildlife - for example, the determination of hunting quotas is still largely the responsibility of central government officials. But the extent of devolution is relatively robust (Jones, 2004; see also Schlager and Ostrom, 1992). Community conservancy are administered by locally elected management committees, retain 100 per cent of the revenue earned from tourism joint ventures and tourist hunting concessions, and determine their own investment partners. Although wildlife user rights are revocable, they are not term-limited (NACSO, 2004).

The reforms providing for the creation of community conservancies in Namibia were motivated by a combination of contextual factors. These include: the conservation gains witnessed on private ranches in the 1970s and 1980s following the transfer of authority over wildlife to private landowners; the promise of community-based programmes initiated in the early 1980s in northwest Namibia by a local conservation organization; and emerging lessons from Zimbabwe's CAMPFIRE programme (Jones and Murphree, 2001). Even more important in spurring the conservancy reforms was Namibian independence from South Africa in 1990. The shift to majority rule, and the opportunities and imperatives it created among policy makers catalysed the extension of the same privileges to communal lands that had already been established on white-owned freehold lands. ${ }^{7}$ There was little or no rurally-based activist movement demanding these reforms. Rather, the reform measures were formulated and implemented primarily by central technocrats. Foreign donors such as USAID have played a major role in providing financial support for conservancy development since the early $1990 \mathrm{~s} .{ }^{8}$ However, they were not initially the champions of institutional reform. Both local NGO's and international conservation organizations such as the World Wildlife Fund have played key roles in the establishment of conservancies. These groups are influential not only in facilitating the

7. This opportunity can be looked at in two ways. On the one hand, independence from South Africa created the opportunity for enlightened policy entrepreneurs within the bureaucracy to grant rural communities rights over resources which were not politically acceptable under Apartheid rule. But independence also created the practical political pressure that if such reforms were not implemented it could render untenable the privileged rights over wildlife held for years by white landowners on freehold lands.

8. Barnett and Patterson (2006) provide an estimate of nearly US\$28 million provided by USAID through the Living in a Finite Environment (LIFE) programme, which has been the main source of donor support to the community conservancies over the past decade. 
Figure 2. Total Value of Tourist Hunting in Namibia Carried out in Different Land Tenure Categories

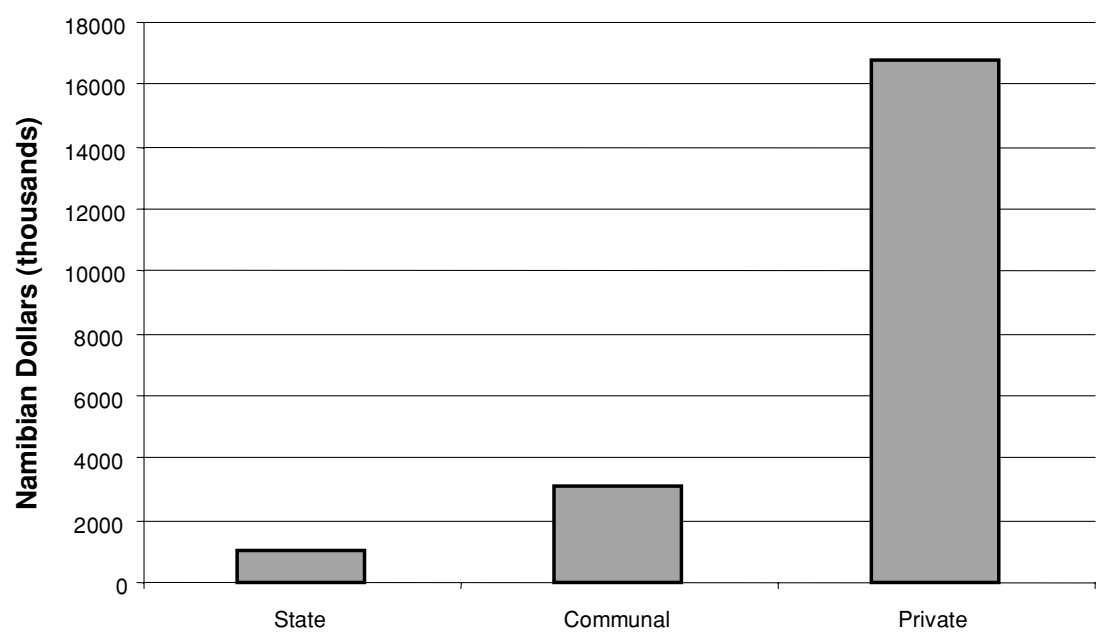

Source: Barnett and Patterson (2006)

implementation of wildlife policy and advocating for devolution, but also in brokering local internal struggles over rights and benefits (Sullivan, 2003).

Institutional elements of Namibia's wildlife utilization and management practices may also have contributed to enabling CBNRM reforms. Namibia's hunting industry has historically been structured differently from Tanzania's system of centrally controlled wildlife utilization. Namibia's tourist hunting industry generates revenue mainly to the owners of private lands where much of the country's wildlife is found; the value of tourist hunting on private lands is about seventeen times that of the value of hunting carried out on state lands (Barnett and Patterson, 2006); see Figure 2.

In addition, when the communal conservancy reforms were initially passed, wildlife populations on communal lands were much reduced from years of over-exploitation and drought. In northwest Namibia, the region where most conservancies have emerged, wildlife numbers were greatly depressed in the $1980 \mathrm{~s}$ - as a result, the value of wildlife in communal areas was perceived as relatively marginal prior to conservancy formation. Indeed, Namibia's hunting industry has grown considerably in recent years, in concert with the creation of communal conservancies and attendant wildlife recoveries. Hunting revenues have risen from NAD 19.6 million in 1992 to NAD 80 million in 2000 (ibid.). 
Hunting administration in Namibia is notably transparent. The concessions that state authorities do control are dispensed through public auction (ibid.). The transparency of wildlife management in Namibia reflects the country's broader macro-political standing as one of sub-Saharan Africa's more wealthy and less corrupt countries (World Bank, 2006). The combination of limited state control over tourist hunting revenues and concessions, low value of wildlife on communal lands prior to conservancy formation, transparent hunting administration procedures, and the generally high quality of national governance institutions all serve to reduce the incentives that state wildlife authorities in Namibia possess to resist devolution of wildlife management to local communities.

\section{Botswana}

Wildlife in Botswana falls under the jurisdiction of the Department of Wildlife and National Parks (DWNP) in the Ministry of Commerce and Industry. Unlike most other countries in the region, Botswana's wildlife policy has attempted to strike a balance between providing access to wildlife to local citizens for their own consumption, and developing a commercial tourist hunting industry (Barnett and Patterson, 2006). In the early 1980s, for example, the bulk of the national hunting quota issued by DWNP was allocated to citizen hunting rather than to the more lucrative trophy hunting enterprises (ibid.).

In Botswana CBNRM emerged in the mid-1980s as a strategy to encourage local conservation practices by providing people benefits from wildlife and other resources. In 1986, the DWNP released a Wildlife Conservation Policy establishing 20 per cent of the country as Wildlife Management Areas where local people could obtain a wildlife quota and either consume it or sell it for profit (Cassidy, 2000). In order to develop commercial ventures, communities must also obtain a land lease from District Land Boards. Leases are granted on fifteen-year terms and enable third-party contracts.

Communities granted a wildlife quota keep 100 per cent of revenues generated by wildlife-based enterprises. Such revenues have averaged up to US\$ 200,000 annually from hunting concessions in parts of northern Botswana (Madzudzo et al., 2006). By 2003 there were sixty-seven registered community trusts, which included 120 villages and 103,000 people (Swatuk, 2005). However, DWNP retains ownership and most management rights such as quota setting, and can revoke the wildlife quota if the community does not abide by conditions placed on management of the area and distribution of revenues. A key difference between Botswana and Namibia is that communal conservancies in Namibia are based on legislative provisions whereas Botswana's system is dependent on administrative discretion and policy (Jones, 2004; Swatuk, 2005). The potential fragility of such arrangements has emerged in recent years as the central government has attempted to reduce local control over wildlife and re-centralize authority at the district 
and national levels. It has cited local mismanagement as the justification (Rihoy and Maguranyanga, 2007).

As in the case of Namibia, increasing local wildlife benefits and the expansion of Botswana's commercial hunting industry have been parallel processes during the past twenty years. Between 1986 and 2001, the value of the country's tourist hunting industry increased from BWP 6.35 million to BWP 59.6 million (Barnett and Patterson, 2006). Although DWNP is responsible for overseeing all wildlife utilization, and granting hunting concessions in areas not managed by communities or private landholders, it receives only an estimated 3.4 per cent of total revenues and until recently, the hunting revenues realized from concessions on state lands went directly to land boards under the Ministry of Lands, rather than to DWNP (ibid.). Hunting concessions are granted through tender processes (ibid.).

Botswana's institutional environment is somewhat paradoxical; the country has one of Africa's most well established democracies, the highest per capita income - overwhelmingly underpinned by diamond mining - and the lowest levels of corruption in sub-Saharan Africa (Transparency International, 2006; World Bank, 2006). Civil servants in Botswana are generally high quality, well-compensated, and accountable (Good, 1992). But Botswana is also dominated by a single party and a relatively small group of elites whose private interests and public functions often intermingle to uphold a patrimonial system of governance (Swatuk, 2005). Civil society is weak and plays little role in holding public leaders to account (Good, 2003).

Botswana's wildlife management reforms have thus occurred in a context of transparent and technically competent - but nevertheless patrimonial - governance, relative economic prosperity and relatively low bureaucratic dependence on wildlife on community lands for revenue. Reforms have been driven principally by central government actors and foreign donors, drawing on experiences with CBNRM elsewhere in southern Africa. Political commitment to local control over wildlife has been erratic and recentralization characterizes debates over CBNRM in recent years. State modernization discourses and elite interests in mining and tourism play a role in this policy reversal, as do ongoing conflicts over resource rights between the government and the San hunter-gatherers in the Kalahari (Rihoy and Maguranyanga, 2007; Swatuk, 2005). Local communities have played at best a small role in motivating community-based reforms in Botswana. The trajectory of reforms is decidedly top-down and at the same time many of the rural communities that have benefited are politically and economically relatively marginal.

\section{Zimbabwe}

Like Namibia, wildlife management in Zimbabwe has been strongly influenced by the country's historical division of land between a proportionately 
small commercial freehold class of landowners and the majority of citizens living in communal lands (Jones and Murphree, 2001). The 1975 Parks and Wildlife Act granted freehold landowners authority over wildlife found on their lands and recognized the principle that 'wildlife was the property of those who lived on the land with it' (Hill, 1996: 108). The result was considerable wildlife increases after this devolution of proprietorship, with approximately $27,000 \mathrm{~km}^{2}$ of Zimbabwe's commercial farming sector becoming devoted to wildlife as a primary land use (Bond, 1993).

After the beginning of majority rule in 1980, Zimbabwean policy makers formulated strategies to extend the ownership of wildlife enjoyed on freehold properties to communal land residents, and amended the 1975 Parks and Wildlife Act accordingly in 1982. The Communal Areas Management Programme for Indigenous Resources (CAMPFIRE) was developed to implement these reforms, and originally sought to devolve similar rights over wildlife to the local level as had been achieved for freehold lands. This was not achieved, however, and CAMPFIRE instead decentralized authority to rural district councils (Murphree, 2005). District councils often retain large proportions of wildlife revenues and this has long been viewed as the greatest institutional weakness of CAMPFIRE, as many of the benefits accrue to district political elites rather than to the local populations who typically bear the costs of living with wildlife (Murombedzi, 1999; see also Dzingirai, 2003). Murphree (2005) analyses CAMPFIRE as essentially a 'strategic compromise' in terms of achieving only limited decentralization in comparison to its objectives of more far-reaching devolution of authority towards the grassroots.

The shift to majority rule created the possibility of and the demand for extension of wildlife rights to communal lands in Zimbabwe, and assured the 1982 legislative reforms of broad political support (Murphree, 2005). The architects of CAMPFIRE were primarily state wildlife agency bureaucrats, working in an effective collaboration with local conservationists, rural extension experts, and academics (Jones and Murphree, 2001). There was little participation by community actors in crafting the reform agenda (Alexander and McGregor 2000). However, as the programme has evolved the CAMPFIRE Association, a membership body that represents local producer communities and links them to higher levels of government, has come to play a greater role. As in Namibia, external donors were not the originators of the reform agenda, but provided substantial financial support to CAMPFIRE - on the order of US\$ 30 million between 1990 and 2003 (Rihoy et al., 2007).

Importantly, the decentralization of wildlife in Zimbabwe did not require central authorities to give up existing wildlife-based income but rather extended formal wildlife-based land uses and enterprises to communal lands where they had previously not existed (Hill, 1996). The presence of commercial trophy hunting in Zimbabwe's communal lands was limited prior to the initiation of CAMPFIRE's reform efforts in the mid-1980s; only 
eleven hunting concessions existed on communal lands in 1986 (Barnett and Patterson, 2006). The development of the CAMPFIRE programme, as with the devolution of management authority to private landholders in the mid1970 s, contributed to the expansion of the country's hunting industry from US\$ 4.2 million in 1984 to US\$ 18.6 million in 1999 (ibid.). The management of Zimbabwe's hunting industry during the past three decades has been relatively transparent and efficient (ibid.).

Since 2000, the profound changes in Zimbabwe's political and economic landscape have altered the dynamics of CBNRM. As a result of soaring inflation and the collapse of the tourism industry, the benefits communities gain from wildlife have declined precipitously in places (Rihoy et al., 2007). But CAMPFIRE has also proven remarkably resilient (Murphree, 2005), and its changed context is leading to new local political negotiations within communities and between communities and district councils over the exercise of authority and devolution (Rihoy et al., 2007).

\section{Zambia}

Efforts to reform wildlife policy in Zambia and enable greater community participation emerged in the early 1980s (Gibson, 1999). Two programmes were developed by government officials, conservationists, and foreign donors that sought to create the means for local people to benefit from wildlife: the Luangwa Integrated Resources and Development Program (LIRDP) and the Administrative Management and Design for Game Management Areas (ADMADE). The LIRDP operated locally in the Luangwa Valley and received funding from the Norwegian government, while ADMADE was a national programme which sought to channel revenues from tourist hunting to local communities across much of the country (Gibson, 1999).

These programmes have successfully channelled significant sums of revenue from wildlife utilization to rural communities in Zambia. ADMADE ostensibly granted local communities about 35-40 per cent of tourist hunting revenues, while LIRDP was able to direct 100 per cent of hunting concession revenues in the Luangwa Valley to locals; both have been widely cited as successful models of southern African CBNRM (see Child and Dalal-Clayton, 2004; Lewis and Alpert, 1997). Although local communities gained access to revenues from wildlife, ${ }^{9}$ neither LIRDP nor ADMADE actually granted communities any statutory rights to wildlife or decision-making authority

9. There have been several changes to the revenue-sharing formulas used under these various programmes. The most recent information (Jones, 2004) indicates that in the Luangwa Valley (LIRDP), communities are to receive 80 per cent of wildlife revenues from hunting, while in other areas locally elected community resource boards receive 45 per cent of revenues, while the local chiefs receive 5 per cent; 40 per cent and 10 per cent go to Zambia Wildlife Authority and central government, respectively. 
over wildlife uses. Zambia has instead focused primarily on redistributing financial benefits from wildlife, rather than redistributing managerial authority (Gibson and Marks, 1995). This has been a major constraint, and critics argue that these programmes have consequently had little positive impact in terms of spurring community investments in sustaining local wildlife populations (Gibson, 1999; Gibson and Marks, 1995; Marks, 2001). Bwalya (2003: 41) reviews one ADMADE site and finds that the actual amount of revenue reaching communities to be around 6 per cent of the total, with "no evidence of significant impact of community wildlife management on local behaviour, community welfare and wildlife conservation'.

The government agency responsible for wildlife is the Zambia Wildlife Authority (ZAWA). ZAWA manages and receives direct revenues from both national parks and wildlife on community lands. Nearly all of Zambia's tourist hunting industry occurs on Game Management Areas, which are occupied by rural communities (Lindsey et al., 2007). Zambia's hunting industry is currently estimated at about US\$ 4-5 million in total annual turnover, although it was worth perhaps US\$ 9 million before being banned for two years in 2001 (DSI, 2004; Lindsey et al., 2007). ZAWA gets about half of its revenues from tourist hunting concessions on community lands - such as those administered under ADMADE - and about half from national park revenues (DSI, 2004). The reliance of ZAWA on hunting revenues from communal lands, which it uses to fund the management of unprofitable and under-funded national parks, ${ }^{10}$ presents a strong institutional disincentive to devolve control over wildlife to local communities (ibid.). As Jones (2004: 39) notes, 'ZAWA is not going to implement approaches that cut off its own funding'. Further, governance-related factors enhance these disincentives (cf. Gibson, 1999). Tourist hunting concessions are not allocated transparently, with Child and Dalal-Clayton (2004: 269) noting that 'senior politicians are heavily involved in hunting concessions'. Zambia's public institutions are perceived as highly corrupt and neo-patrimonial in nature (Transparency International, 2006; see also ECA, 2005).

\section{Mozambique}

In Mozambique, CBNRM has evolved in a context that is quite different from that of its neighbours. The end of the civil war in 1992 led to a period of institutional reform, with new opportunities for various forms of local participation and empowerment (Anstey, 2005). For example, the 1997 land reforms recognized traditional lands rights and provided the opportunity for formalizing communal tenure (Norfolk and Tanner, 2007).

10. Zambia earns only US\$ 0.75 per acre from its parks, compared to US\$ 17.50 per acre in South Africa; no parks have yet been able to cover their costs financially (DSI, 2004). 
Community participation in wildlife management is explicitly endorsed in wildlife and forestry policy (1997), law (1999), and subsequent regulations (2001), with local communities being identified as principal actors in implementing the policy (Anstey, 2001; Nhantumbo et al., 2003). Communities can apply to receive user rights and management authority for wildlife, although the way these rights can be devolved and exercised has been left somewhat ambiguous. Although communities are now able to formalize collective rights to land, Anstey (2005: 162) notes that 'there is no equivalent community right to natural resources as there is to land and no developed mechanism to gain clear or exclusive user rights'. Set against this legal ambiguity, Virtanen (2005: 10) cautions that communities are in danger of becoming 'powerless facades to legitimize decisions made elsewhere'.

Despite these constraints, local experimentation has continued, based more on de facto negotiations over resource rights and access than on de jure devolution of authority for wildlife to the local level. The Chipanje Chetu project in northern Mozambique was able to generate nearly US\$ 15,000 by 2005 in local revenues from a tourist hunting concession located on $6,500 \mathrm{~km}^{2}$ of communally titled land (Norfolk and Tanner, 2007). In another local initiative, the community and a private hunting operator have collaborated to pressure government authorities to approve a negotiated benefit-sharing arrangement (ibid.).

Broader political-economic trends in Mozambique, coupled with the ambiguity of wildlife legislation, constrain the emergence of local jurisdictions over wildlife resources. Mozambique has high levels of institutional corruption, bordering on the criminalization of state institutions (Anstey, 2005). As in Tanzania, the liberalization of the economy and growth of foreign private investment has enhanced the rents available to public officials exercising discretionary powers, as well as the direct involvement of those officials in private enterprises exploiting public resources. This can affect wildlife management reform outcomes directly, such as in the aforementioned Chipanje Chetu project, where community income from tourist hunting was undermined by the revocation of that hunting concession, apparently as a result of collusion between a competing hunting operator and some political elite (Norfolk and Tanner, 2007). State-private linkages are also driving the expansion of state protected areas — by 36,000 $\mathrm{km}^{2}$ between 1997 and 2002 - and by providing attractive new sites for private investment, often from neighbouring South Africa (Anstey, 2005).

However, in contrast to other countries in southern Africa, Mozambique's commercial wildlife sector is relatively limited in its scale. Wildlife populations were unmanaged, over-exploited, and depleted during the long civil war. A tourist hunting industry has been developed since 1992, but this is mostly concentrated in the remote northern part of the country. No published data are available on the economic value of tourist hunting in Mozambique, but it is almost certainly lower than any of the other six countries covered here. 
Institutional reforms in Mozambican wildlife management are subject to diverse influences and origins. The wildlife and forestry legislative reforms of the late 1990s were dominated by government officials, foreign donors and international conservation organizations, with rural communities effectively 'offstage' (Anstey, 2001). Communities have, however, played a greater role more recently in terms of local negotiations over project development and resource uses. Donor funding to CBNRM in Mozambique has been somewhat inconsistent, with a surge in support for natural resource management in the late 1990s to the extent of US\$ 31 million in new projects (Anstey, 2005). Mozambican policy makers thus have some incentives to pursue community-based reforms to legitimize donor support for wildlife and other natural resource sectors.

\section{Kenya}

Kenya's wildlife sector has taken a singular course during the past thirty years. Kenyan wildlife policy has long been supportive of private and community rights to manage and benefit from wildlife (Barrow et al., 2000). In contrast, administrative actions have worked to progressively centralize and limit private and communal landholders' rights and opportunities since the 1970s, at least for consumption uses of wildlife. A key event was a presidential ban in 1977 on all forms of hunting that remains in place to this day. As a result, Kenya is the only country in east and southern Africa with a sizeable wildlife population that does not allow any commercial hunting. In 1989, Kenya's Wildlife and Game Management Division, which was highly corrupt and linked to rampant commercial poaching with estimates that government guards were responsible for one-third of all rhino poaching incidents, was replaced by the parastatal Kenya Wildlife Service (KWS) (Gibson, 1999).

During the 1990s KWS strategically promoted community-based management with a renewed emphasis on landholder incentives and economic benefits from wildlife to help sustain the estimated 60-75 per cent of Kenya's wildlife population that lives outside protected areas (Barrow et al., 2000). The leadership of KWS at that time was highly supportive of CBNRM, including the re-introduction of commercial hunting to increase the value of wildlife to rural landholders (Baskin, 1994). With donor backing, KWS supported the formation of local wildlife associations which were intended to provide a link between rural landholders and central authorities.

A range of new community-based ecotourism initiatives emerged from these efforts in the mid and late 1990s, but the efforts to reform legislation and devolve greater authority over wildlife to landholders and re-introduce hunting were defeated. Similar reform efforts have continued intermittently during the past decade, although the leadership for these reforms has shifted from KWS to a loose network of conservation organizations and grassroots activists. In 2004-05, a group of conservation organizations and local 
landholder representatives ${ }^{11}$ succeeded in working with members of parliament to pass legislation through parliament that would have significantly decentralized wildlife management in Kenya. This bill was subsequently vetoed by the president following intensive lobbying by international animal welfare and conservation organizations opposed to hunting and which have used their financial resources to build local, largely urban-based, constituencies in Kenya (Norton-Griffiths, 2007).

In Kenya, bureaucratic interests have no real direct financial stake in wildlife on private lands. In fact, most of wildlife's economic value is not captured by any actor because of the hunting ban. Grassroots and civil society advocacy organizations are relatively strong and active, and have played a notably prominent role in wildlife policy reform processes in recent years. The main cause of failed reforms is the strength of countervailing perspectives on how wildlife should be managed in Kenya, in particular the views of influential foreign animal welfare groups (ibid.). During the past ten years these groups have forged close relationships, including through extensive financial support, with state wildlife authorities. These relationships have helped transplant both their interests and ideology. Kenya's tourism industry, which benefits considerably from the hunting ban through reduced competition for access to wildlife-rich lands, is also an important lobby for the status quo.

\section{EXPLAINING CBNRM REFORM OUTCOMES IN EAST AND SOUTHERN AFRICA}

Several basic patterns emerge from the above summary reviews of wildlife management reforms in east and southern Africa. The outcomes of reform efforts in the region have been highly dependent on the interests of central government actors, and the extent to which they have initiated reforms convincingly. In countries where institutional reforms have occurred (Namibia, Botswana and Zimbabwe), actors within the state wildlife bureaucracy played a key role in effecting changes, just as in Tanzania the key determinant of reform outcomes has been the extent to which central wildlife authorities have sought to maintain control.

A fundamental factor that influences the incentives of policy makers is the benefits from discretionary centralized control of wildlife (Gibson, 1999). These benefits are in turn shaped by the size and structure of the tourist hunting industry. The financial value of trophy hunting activities, when directly controlled by state agencies and carried out on community lands, amplifies incentives to maintain control and to resist devolutionary reforms. For example, both the size of Tanzania's hunting industry and its extensive

11. Organized as the Kenya Wildlife Working Group which was then hosted by the East African Wildlife Society. 
reliance on concessions on community lands are central to understanding why reforms have been generally unsuccessful. In Zambia, the value of hunting is much lower, but virtually the entire tourist hunting industry is dependent on concessions on community lands. Botswana and Namibia, by contrast, have smaller hunting industries than Tanzania, but more importantly, the commercial utilization of wildlife on communal lands was never as centrally controlled as it has been and continues to be today in Tanzania and Zambia. In Namibia, in sharp contrast to Tanzania and Zambia, most hunting revenues accrue not to state authorities but to private landholders and, following reforms, communal landholders. Our analysis thus suggests that the scale of rent-seeking opportunities for central policy makers from wildlife on communal lands is in general inversely related to the political will to devolve authority for wildlife management to the local level.

Rent-seeking opportunities are not, however, only a function of patterns of commercial wildlife utilization. They are also affected by the broader institutional environment in which bureaucrats operate. The transparency and accountability of governing institutions is a basic determinant of the ability of public officials to capture wildlife's economic value and use it for patronage purposes or personal profit. Unaccountable and non-transparent institutions enhance the ability of public officials to privatize the values of public resources such as wildlife, which increases incentives to gain and consolidate central control over those resources.

In terms of the governance factors shaping the utilization of wildlife, a useful indicator is whether countries use transparent and/or public bidding and auction procedures in determining the allocations of wildlife use. The more transparent the mechanisms for allocating commercial wildlife use rights, the lower the rents public officials can extract by virtue of their gatekeeper status. Broader governance factors including the rule of law are additionally important in terms of the level of accountability demanded of public institutions and individual state agents. The association between lower levels of corruption and higher per capita incomes in sub-Saharan Africa (ECA, 2005) suggests that that higher wealth in countries such as Namibia and Botswana helps improve the remuneration of civil servants and changes their cost-benefit calculations in relation to rent seeking. The relative poverty of civil servants operating in weak institutional environments is a source of wildlife mismanagement. As Barnett and Patterson (2006: iii) note, 'the very low salaries paid to wildlife personnel and the lack of transparent and accountable oversight processes' increase corruption in the management of hunting concessions. Figure 3 provides basic governance rankings for six of the seven countries included in this study, with Namibia and Botswana clearly standing apart as having much higher quality governing institutions. Zimbabwe is not included because its current rankings fail to capture the fact that it had a relatively high quality bureaucracy during the 1970s and 1980 s, and its wildlife agency in particular was regarded as one of Africa's most technically proficient. 
Table 1. Key Variables Influencing Central Actors' Incentives and Disincentives to Devolve Authority for Wildlife to Local Communities, and Actual Devolution Achieved

\begin{tabular}{lccccc}
\hline & $\begin{array}{c}\text { Value of } \\
\text { Centralized } \\
\text { Commercial } \\
\text { Utilization of } \\
\text { Wildlife on } \\
\text { Community Lands }\end{array}$ & $\begin{array}{c}\text { Transparency } \\
\text { of Procedures } \\
\text { for Allocation } \\
\text { of Wildlife } \\
\text { Use (Hunting) } \\
\text { Concessions }\end{array}$ & $\begin{array}{c}\text { Overall } \\
\text { Governance } \\
\text { Transparency }\end{array}$ & $\begin{array}{c}\text { Disincentives } \\
\text { for Central } \\
\text { Authorities to } \\
\text { Devolve } \\
\text { Authority over } \\
\text { Wildife }\end{array}$ & $\begin{array}{c}\text { Level of } \\
\text { Devolution } \\
\text { Carried Out }\end{array}$ \\
\hline Namibia & Low & High & Medium & Low & High \\
Botswana & Low & High & High & Low & Medium \\
Zimbabwe & Low & High & Low & Low & Medium \\
Zambia & High & Low & Low & High & Low \\
Mozambique & Medium & Medium & Low & Medium & Low \\
Tanzania & High & Low & Low & High & Low \\
Kenya & Low & n/a & Low & Low & Low \\
\hline
\end{tabular}

What Figure 3 illustrates, building on the country case reviews, is that CBNRM in the region has taken place in two very different institutional settings, with decidedly different outcomes (see Table 1). Namibia, Botswana, and pre-crisis Zimbabwe are or were relatively ordered nation states where the rule of law operates and public institutions are reasonably efficient. This does not mean that these countries are western-style democracies with vibrant pluralism, but it does mean that the private appropriation of public resources by government officials is constrained. It is in these three countries that institutional reforms to devolve or decentralize wildlife management to lower levels of society have been most substantial. In contrast, Zambia,

Figure 3. Measures of Governance in Wildlife-rich African Nations

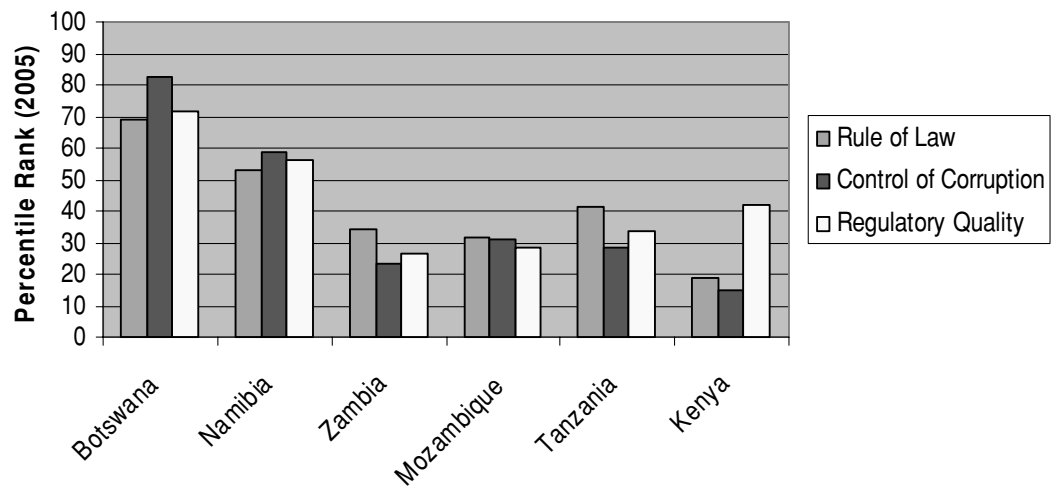

Source: Based on data from Kaufmann et al. (2006) High percentile scores reflect high quality in a given category. 
Mozambique, Kenya and Tanzania are countries that more broadly reflect governance norms in sub-Saharan Africa: the dominance of state institutions by informal neo-patrimonial relationships, the instrumentalism of disorder and ambiguity for political ends, the collusive private appropriation of public resources and weak rule of law (see also Chabal and Daloz, 1999; van de Walle, 2001). In these countries, the devolution of valuable natural resources such as wildlife to the local level is fundamentally at odds with the interests and incentives that dominate governance processes.

It is notable that in most of the countries reviewed here, the level of local participation in policy reform processes has not been a central factor in wildlife sector reform outcomes to date. In fact, there is little evidence of significant local or bottom-up influence on these institutional processes in any of the countries reviewed here. The most notable national example of an active civic and locally-based reform lobby, Kenya, is nevertheless an unsuccessful case of reform. ${ }^{12}$

This lack of local influence on wildlife management reforms in Africa is notable, given that in some other parts of the world strong cases of longterm CBNRM have been prompted by local resistance to state management practices. For example, Agrawal and Ostrom (2001: 488) review four cases of forest policy decentralization in India and Nepal, finding that 'local mobilization is critical' to the long term success of reform outcomes. The relative lack of influence of local communities and civil society in African CBNRM experiences may reflect the dominant role of governing elites and foreign donors in broader economic policy formulation and decision-making processes (van de Walle, 2001).

With respect to foreign donors, a final point needs to be made. The level of external donor support plays a highly variable role in reform outcomes, but in no instance have donors been the principle driving force behind the adoption of reforms. All countries reviewed here have received substantial support from donors and international conservation organizations explicitly promoting CBNRM, and we can conservatively estimate that since 1990 between $\$ 100$ million and $\$ 200$ million in aid may have been spent promoting CBNRM in the seven countries (see Anstey, 2005; Baldus et al., 2003; Barnett and Patterson, 2006; Gibson, 1999; Rihoy et al., 2007). Where the presence and leadership of donors has been most pronounced, such as in Tanzania and Zambia since the late 1980s, reforms have nevertheless been undermined by the structure of incentives governing policy makers' interests and choices.

This suggests that the capacity of donors to influence the outcomes of CBNRM reform processes is limited, even if they play a strong role in

12. Despite the ultimate failure of those efforts, it is notable that these activists did succeed in passing wildlife legislation reform through parliament before the bill was vetoed by the president. This was achieved almost solely by civic activists with little or no leadership from state wildlife authorities and substantial opposition from large international NGOs. 
the initiation of reforms. If government policy makers are disinclined to implement reforms even while receiving aid funds, donor efforts can get completely annulled. International donors seeking to promote CBNRM often cast institutional and political problems as technical ones, and often avoid the need to address underlying political economic barriers to change (Ferguson, 1994; Gibson et al., 2005). Indeed, regional CBNRM outcomes reinforce broader findings regarding the relationship between foreign aid and policy reform in Africa: namely that the ability of donors to force reforms is limited and ultimately dependent on leadership from government policy makers (Devarajan et al., 2001).

\section{IMPLICATIONS FOR CBNRM}

A number of practical implications emerge from our analysis for the design and application of CBNRM in sub-Saharan Africa, and perhaps elsewhere. CBNRM is likely to be most effective where the value of resources is high and local rights to those resources are secure. However, CBNRM reforms are beset with a fundamental dilemma in that valuable resources are also those which create the strongest incentives for central actors to maintain control, particularly in the context of weak governance institutions (Murphree, 2004). By contrast, CBNRM is most likely to be politically possible in circumstances where resource values are either low or have a number of other effective claimants in addition to central institutions and authorities. This pattern has been documented in several cases of community-based forestry decentralization efforts as well, in Africa and in other parts of the world such as Nepal (for example, Ribot, 2004; Ribot et al., 2006). ${ }^{13}$

In terms of better negotiating the institutional barriers facing CBNRM, there is a need to take greater account of the link between natural resource management and macro-political context and to recognize the futility of attempting to address natural resource governance issues in isolation from the broader political environment. This highlights the imperative of a longterm, adaptive, and flexible approach to promoting CBNRM, which must be grounded in the local and national political arena. The long-term growth of civil society and local communities' capacity to influence the institutional arrangements governing wildlife and other resources are fundamental to the future positive evolution of CBNRM.

13. Ribot et al. (2006) note that in Nepal's community forest management program most local management units have been created in the relatively low value forests of Nepal's hill country, whereas in the higher value forests of the Terai region there has been very little devolution of forest control to local communities. Ribot (2004: 51) generalizes this principle across decentralization case studies: 'The overriding principle that governments seem to be following is: keep everything of value centralized and transfer centrally defined obligations to lower-level authorities'. 
Donor and NGO support to CBNRM in sub-Saharan Africa is often based on technocratic approaches to policy formulation and locally-situated, relatively short-term projects. Given the very nature of development aid as a quasi-diplomatic transaction between donor and recipient governments, the vast majority of external support to CBNRM is channelled to centralized bureaucratic institutions. Donor CBNRM reform narratives generally consist of, as Anstey (2005: 144) describes in the case of Mozambique, 'the premise of ordered dispersal of governance downwards (power, accountability, authority) from an enabling effective centre'. Where central interests have strong disincentives to be 'enabling' due to formal and informal neo-patrimonial interests, this premise is deeply flawed. It is therefore unsurprising that donor investments in such contexts often fail to catalyse the intended institutional reforms. All of this suggests the need to reformulate the ways that external donor agencies or conservation organizations support CBNRM if these strategies are to have greater impact.

This reformulation must address the fundamental incompatibility, in African neo-patrimonial governance contexts, between centrally-channelled development aid and the politicized nature of CBNRM as a process of institutional adaptation and negotiation. Our findings suggest that external support to CBNRM in many African contexts must prioritize investments in local capacity to negotiate for resource rights, improvements in information sharing about how proceeds from tourist hunting are spent, and more transparent processes for allocating hunting rights and concessions even if central authorities retain the powers of allocation. Support to communities will inherently need to be decentralized and routed through local and civic organizations and associations in preference over or at least in addition to the administrative structures of the state.

A final factor in the efforts to reformulate and revitalize CBNRM efforts in sub-Saharan Africa concerns the incentives of donor agencies themselves. Like public officials in African state wildlife agencies, aid donors operate according to their own set of institutional incentives (Gibson et al., 2005). CBNRM may require long-term approaches and flexible and locally adaptive investments, but such an investment framework is often at odds with the incentive structures of most aid agencies and their personnel (ibid.). Thus while an institutional understanding of CBNRM suggests the need to invert support for these processes from their current top-down conventions, we recognize that the conventional approaches themselves will likely be resistant to change. But some institutional changes - such as in information availability and auction processes - may turn out to be feasible even without substantial changes in incentives of donor agencies, and over time will have the potential to encourage change. At any rate, creative strategies are needed to encourage and mobilize local support so that there is greater devolution of resource rights even in the face of existing constraints. 


\section{CONCLUSION}

This study has examined the institutional and political dimensions of CBNRM and decentralized wildlife governance in seven east and southern African countries. Its key finding is that high financial wildlife values captured by state agents, especially when coupled with high levels of corruption, create strong disincentives for central managers to devolve authority over wildlife to local communities. Where CBNRM reforms have occurred, the institutional context is distinguished by stronger public institutions, notably lower levels of corruption, and relatively lower wildlife value that state actors can capture. The conjunction of these latter factors has been of basic importance in creating the enabling institutional environment that favours innovation within state wildlife agencies. Additionally, our review of evidence indicates that neither donors nor local communities have played a determining role in the adoption of key institutional reforms related to wildlife management in the studied countries.

Given the small number of cases in our analysis, we have followed an analytical approach that relies on examination of causal processes within the cases and their comparison across cases. Inevitably, our analytical goals have led us to examine institutional and political processes primarily at the central level. This is of course not to suggest the lack of local and sub-national variations around institutional functions and performance. However, our approach suggests that national level political and institutional processes strongly structure decision making at that level and are necessary to understand if the goal is to explain the institutional outcomes of natural resource governance reforms.

Much of the CBNRM discourse in sub-Saharan Africa continues to focus on technical issues relating to how policies should be designed, rather than the political means of achieving them (see Jones, 2004). New strategies for supporting CBNRM that explicitly incorporate a political-economic understanding of the forces inhibiting or enabling key reforms are essential. These strategies will likely look very different from the centralized, project-based partnership models that donors and conservation NGOs have employed for the past twenty years, and indeed may not be easily adapted to these actors' organizational incentives. Practitioners will thus need not only better analyses of the political and institutional variables that determine reform outcomes, but also new models for applying that knowledge to improve programmatic support to community-based natural resource management.

\section{REFERENCES}

Agrawal, A., A. Chhatre and R. Hardin (2008) 'Changing Governance of the World's Forests', Science 320(5882): 1460-2.

Agrawal, A. and E. Ostrom (2001) 'Collective Action, Property Rights, and Decentralization in Resource Use in India and Nepal', Politics and Society 29(4): 485-514. 
Agrawal, A. and J.C. Ribot (1999) 'Accountability in Decentralization: A Framework with South Asian and West African Cases', The Journal of Developing Areas 33: 473-502.

Alexander J. and J. McGregor (2000) 'Wildlife and Politics: CAMPFIRE in Zimbabwe', Development and Change 31(3): 605-27.

Anstey, S. (2001) 'Necessarily Vague: The Political Economy of Community Conservation in Mozambique', in D. Hulme and M. Murphree (eds) African Wildlife \& Livelihoods: The Promise and Performance of Community Conservation, pp. 74-87. Oxford: James Currey Ltd.

Anstey, S. (2005) 'Governance, Natural Resources and Complex Adaptive Systems: A CBNRM Study of Communities and Resources in Northern Mozambique', in V. Dzingirai and C. Breen (eds) Confronting the Crisis in Community Conservation: Case Studies from Southern Africa, pp. 138-93 Pietermaritzburg: University of KwaZulu-Natal.

Baldus, R.D. and A.E. Cauldwell (2004) 'Tourist Hunting and its Role in Development of Wildlife Management Areas in Tanzania'. Proceedings of the Sixth International Game Ranching Symposium, Paris (6-9 July). Paris: International foundation for the conservation of wildlife

Baldus, R., B. Kibonde and L. Siege (2003) 'Seeking Conservation Partnerships in the Selous Game Reserve, Tanzania', Parks 13(1): 50-61.

Blanc, J.J., R.F.W. Barnes, G.C. Craig, H.T. Dublin, C.R. Thouless, I. Douglas-Hamilton and J.A. Hart (2007) African Elephant Status Report 2007: An Update from the African Elephant Database. Gland: IUCN.

Barnes, J.I. and J.L.V. de Jager (1995) 'Economic and Financial Incentives for Wildlife Use on Private Land in Namibia and the Implications for Policy'. Research Discussion Paper No 8. Windhoek: Ministry of Environment and Tourism.

Barnett, R. and C. Patterson (2006) Sport Hunting in the Southern African Development Community (SADC) Region: An Overview. Johannesburg: TRAFFIC East/Southern Africa.

Barrow, E., H. Gichohi and M. Infield (2000) Rhetoric or Reality? A Review of Community Conservation Policy and Practice in East Africa. Evaluating Eden Series No 5. London and Nairobi: International Institute for Environment and Development and the World Conservation Union (IUCN).

Baskin, Y. (1994) 'There's a New Wildlife Policy in Kenya: Use It or Lose It', Science 265: $733-4$.

Batterbury, S.P.J. and J.L. Fernando (2006) 'Rescaling Governance and the Impacts of Political and Environmental Decentralization: An Introduction', World Development 34(11): 185163.

Blaikie, P. (2006) 'Is Small Really Beautiful? Community-Based Natural Resource Management in Malawi and Botswana', World Development 34(11): 1942-57.

Bond, I. (1993) 'The Economics of Wildlife and Land Use in Zimbabwe: An Examination of Current Knowledge and Issues'. Multispecies Animal Production Systems Project, Project Paper No 36. Harare: World Wide Fund for Nature.

Boone, C. (2003) Political Topographies of the African State: Territorial Authority and Institutional Choice. Cambridge: Cambridge University Press.

Brockington, D. (2006) 'The Politics and Ethnography of Environmentalisms in Tanzania', African Affairs 105: 97-116.

Brosius, J.P., A.L. Tsing, and C. Zerner (2005) Communities and Conservation: Histories and Politics of Community-Based Natural Resource Management. Walnut Creek, CA: Altamira Press.

Bwalya, S.M. (2003) 'Understanding Community-Based Wildlife Governance in Southern Africa: A Case Study from Zambia', AJEAM-RAGEE 7: 41-60.

Cassidy, L. (2000) 'CBNRM and Legal Rights to Resources in Botswana'. CBNRM Support Programme Occasional Paper No 4. Gabarone: IUCN.

Chabal, P. and J.P. Daloz (1999) Africa Works: Disorder as Political Instrument. Oxford: James Currey Ltd. 
Child, B. and B. Dalal-Clayton (2004) 'Transforming Approaches to CBNRM: Learning from the Luangwa Experience in Zambia', in T.O. McShane and M.P. Wells (eds) Getting Biodiversity Projects to Work: Towards more Effective Conservation and Development, pp. 256-89. New York: Columbia University Press.

Devarajan, S., D.R. Dollar and T. Holmgren (eds) (2001) Aid and Reform in Africa. Washington, DC: The World Bank.

Development Services and Initiatives (DSI) (2004) 'A Financial and Economic Analysis of the Costs and Benefits of Managing the Protected Area Estate'. UNDP/GEF Funded Project on Reclassification and Sustainable Management of Zambia's Protected Area Systems. Lusaka: Ministry of Tourism, Environment and Natural Resources.

Dzingirai, V. (2003) 'The New Scramble for the African Countryside', Development and Change 34(2): 243-63.

ECA (2005) African Governance Report 2005. Addis Ababa: Economic Commission for Africa.

Fabricius, C., E. Koch, H. Magome and S. Turner (2004) Rights, Resources, \& Rural Development: Community-based Natural Resource Management in Southern Africa. London: Earthscan.

Ferguson, J. (1994) The Anti-politics Machine: 'Development', Depoliticization, and Bureaucracy in Lesotho. Minneapolis, MN: University of Minnesota Press.

Gibson, C.C. (1999) Politicians and Poachers: The Political Economy of Wildlife Policy in Africa. Cambridge: Cambridge University Press.

Gibson, C.C., K. Andersson, E. Ostrom and S. Shivakumar (2005) The Samaritan's Dilemma: The Political Economy of Development Aid. Oxford: Oxford University Press.

Gibson, C. and S. Marks (1995) 'Transforming Rural Hunters into Conservationists: An Assessment of Community-Based Wildlife Management Programs in Africa', World Development 23(6): 941-57.

Goldman, M. (2003) 'Partitioned Nature, Privileged Knowledge: Community-Based Conservation in Tanzania', Development and Change 34(5): 833-62.

Good, K. (1992) 'Interpreting the Exceptionality of Botswana', The Journal of Modern African Studies 30(1): 69-95.

Good, K. (2003) 'Bushmen and Diamonds: (Un)Civil Society in Botswana'. Discussion Paper 23. Uppsala: Nordiska Afrikainstitutet.

Hill, K.A. (1996) 'Zimbabwe's Wildlife Utilization Programs: Grassroots Democracy or an Extension of State Power', African Studies Review 39(1): 103-21.

Hulme, D. and M. Murphree (2001) African Wildlife \& Livelihoods: The Promise and Performance of Community Conservation. Oxford: James Currey Ltd.

Hutton, J., W.M. Adams and J.C. Murombedzi (2005) 'Back to the Barriers? Changing Narratives in Biodiversity Conservation', Forum for Development Studies 2: 341-70.

Hyden, G. (1980) Beyond Ujamaa in Tanzania: Underdevelopment and an Uncaptured Peasantry. London: Heinemann Educational.

Igoe, J. (2004) Conservation and Globalization: A Study of National Parks and Indigenous Communities from East Africa to South Dakota. Belmont, CA: Wadsworth/Thomson Learning.

Igoe, J. and B. Croucher (2007) 'Conservation, Commerce, and Communities: The Story of Community-based Wildlife Management in Tanzania's Northern Tourist Circuit', Conservation and Society 5(4): 534-61.

Jones, B.T.B. (2004) 'Synthesis of the Current Status of CBNRM Policy and Legislation in Botswana, Malawi, Mozambique, Namibia, Zambia, and Zimbabwe'. Report prepared for WWF SARPO. Harare: WWF.

Jones, B. and M. Murphree (2001) 'The Evolution of Policy on Community Conservation in Namibia and Zimbabwe', in D. Hulme and M. Murphree (eds) African Wildlife \& Livelihoods: The Promise and Performance of Community Conservation, pp. 38-58. Oxford: James Currey Ltd.

Jones, B.T.B. and M.W. Murphree (2004) 'Community-Based Natural Resource Management as a Conservation Mechanism: Lessons and Directions', in B. Child (ed.) Parks in Transition: Biodiversity, Rural Development, and the Bottom Line, pp. 63-103. London: Earthscan. 
Kaufmann, D., A. Kraay and M. Mastruzzi (2006) 'Governance Matters V: Governance Indicators for 1996-2005'. Washington, DC: The World Bank. www.worldbank.org/ wbi/governance/govmatters5 (accessed 7 December 2006).

Kelsall, T. (2002) 'Shop Windows and Smoke-filled Rooms: Governance and the Repoliticisation of Tanzania', Journal of Modern African Studies 40(4): 597-619.

Kull, C.A. (2002) 'Empowering Pyromaniacs in Madagascar: Ideology and Legitimacy in Community-Based Natural Resource Management', Development and Change 33(1): 5778.

Lewis, D.M. and P. Alpert (1997) 'Trophy Hunting and Wildlife Conservation in Zambia', Conservation Biology 11: 59-68.

Lindsey, P.A., P.A. Roulet and S.S. Romañach (2007) 'Economic and Conservation Significance of the Trophy Hunting Industry in Sub-Saharan Africa', Biological Conservation 134: 45569.

Madzudzo, E., J. HaBarad and F. Matose (2006) 'Outcomes of Community Engagement in Community-based Natural Resource Management Programmes'. Policy Brief No 22. Cape Town: Programme for Land and Agrarian Studies, University of Western Cape.

Marks, S.A. (2001) 'Back to the Future: Some Unintended Consequences of Zambia's Community-Based Wildlife Program (ADMADE)', Africa Today 48(1): 121-41.

Ministry of Natural Resources and Tourism (MNRT) (1998) The Wildlife Policy of Tanzania. Dar es Salaam: Government Printer.

Ministry of Natural Resources and Tourism (MRNT) (2002) The Wildlife Conservation (Wildlife Management Areas) Regulations. Dar es Salaam: Government Printer.

Murombedzi, J.C. (1999) 'Devolution and Stewardship in Zimbabwe's CAMPFIRE Programme', Journal of International Development 11: 287-93.

Murphree, M.W. (2004) 'Communal Approaches to Natural Resource Management in Africa: From Whence and to Where?', Journal of International Wildlife Law and Policy 7: 203-16.

Murphree, M.W. (2005) 'Congruent Objectives, Competing Interests, and Strategic Compromise: Concept and Process in the Evolution of Zimbabwe's CAMPFIRE, 1984-1996', in J.P. Brosius, A.L. Tsing and C. Zerner (eds) Communities and Conservation: Histories and Politics of Community-based Natural Resource Management, pp. 105-47. Walnut Creek, CA: AltaMira Press.

Namibian Association of CBNRM Support Organizations (NACSO) (2004) Namibia's Communal Conservancies: A Review of Progress and Challenges. Windhoek: NACSO.

Nelson, F., R. Nshala, and W.A. Rodgers (2007) 'The Evolution and Reform of Tanzanian Wildlife Management', Conservation and Society 5(3): 232-61.

Neumann R.P. (1997) 'Primitive Ideas: Protected Area Buffer Zones and the Politics of Land in Africa', Development and Change 28(3): 559-82.

Neumann, R.P. (1998) Imposing Wilderness: Struggles over Livelihoods and Nature Preservation in Africa. Berkeley, CA: University of California Press.

Nhantumbo, I., S. Norfolk and J. Pereira (2003) 'Community Based Natural Resources Management in Mozambique: A Theoretical or Practical Strategy for Local Sustainable Development? The Case Study of Derre Forest Reserve'. Sustainable Livelihoods in Southern Africa Research Paper No 10. Brighton: Institute of Development Studies, University of Sussex.

Norfolk, S. and C. Tanner (2007) 'Improving Tenure Security for the Rural Poor. MozambiqueCountry Case Study'. Legal Empowerment of the Poor Working Paper No 5. Rome: Food and Agriculture Organization of the United Nations.

Norton-Griffiths, M. (2007) 'How Many Wildebeest do You Need?', World Economics 8: 41-64.

Nshala, R. (1999) 'Granting Hunting Blocks in Tanzania: The Need for Reform'. Policy Brief No 5. Dar es Salaam: Lawyers' Environmental Action Team.

Olowu, D. (2003) 'Local Institutional and Political Structures and Processes: Recent Experience in Africa', Public Administration and Development 23: 41-52.

Ostrom, E. (1990) Governing the Commons: The Evolution of Institutions for Collective Action. Cambridge: Cambridge University Press. 
Overton, G. (1998) 'The Good, the Bad and the Ugly', Swara 20(6): 22-4.

Ribot, J.C. (2004) Waiting for Democracy: The Politics of Choice in Natural Resource Decentralization. Washington, DC: World Resources Institute.

Ribot, J.C., A. Agrawal and A.M. Larson (2006) 'Recentralizing while Decentralizing: How National Governments Reappropriate Forest Resources', World Development 34(11): 1864 86.

Rihoy, E.C., C. Chirozva, and S. Anstey (2007) "People are not Happy": Speaking up for Adaptive Natural Resource Governance in Mahenye'. Occasional Paper No 31. Cape Town: Programme for Land and Agrarian Studies, University of Western Cape.

Rihoy, E.C. and B. Maguranyanga (2007) 'Devolution and Democratisation of Natural Resource Management in Southern Africa: A Comparative Analysis of CBNRM Policy Processes in Botswana and Zimbabwe'. CASS-PLAAS CBNRM Occasional Paper No 18. Cape Town: Programme for Land and Agrarian Studies, University of Western Cape.

Schlager, E. and E. Ostrom (1992) 'Property Rights Regimes and Natural Resources: A Conceptual Analysis', Land Economics 68(3): 249-62.

Scott, J.C. (1985) Weapons of the Weak: Everyday Forms of Peasant Resistance. New Haven, CT: Yale University Press.

Shackleton, S., B. Campbell, E. Wollenberg and D. Edmunds (2002) 'Devolution and Community-Based Natural Resource Management: Creating Space for Local People to Participate and Benefit?'. Natural Resource Perspectives No 76. London: Overseas Development Institute.

Songorwa, A.N. (1999) 'Community-Based Wildlife Management (CBWM) in Tanzania: Are the Communities Interested?', World Development 27(12): 2061-79.

Stoner, C., T. Caro, S. Mduma, C. Mlingwa, G. Sabuni, M. Borner and C. Schelten (2007) 'Changes in Large Herbivore Populations across Large Areas of Tanzania', African Journal of Ecology 45: 202-15.

Sundet, G. (1997) 'The Politics of Land in Tanzania'. PhD Thesis, University of Oxford.

Sunseri, T. (2005) "“Something Else to Burn”: Forest Squatters, Conservationists, and the State in Modern Tanzania', Journal of Modern African Studies 43: 609-40.

Sullivan, S. (2003) 'Protest, Conflict and Litigation: Dissent or Libel in Resistance to a Conservancy in North-west Namibia', in E. Berglund and D.G. Anderson (eds) Ethnographies of Conservation: Environmentalism and the Distribution of Privilege, pp. 69-86. Oxford: Berghahn Press.

Swatuk, L.A. (2005) 'From "Project" to "Context": Community Based Natural Resource Management in Botswana', Global Environmental Politics 5(3): 95-124.

Transparency International (2006) 'Corruption Perceptions Index 2006'. http://www. transparency.org/policy_research/surveys_indices/cpi/2006 (accessed 8 December 2006).

United Republic of Tanzania (URT) (2005) 'State of the Public Service Report 2004'. President's Office, Public Service Management, Dar es Salaam, Tanzania.

Virtanen, P. (2005) 'Community-Based Natural Resource Management in Mozambique: A Critical Review of the Concept's Applicability at Local Level', Sustainable Development 13: $1-12$.

van de Walle, N. (2001) African Economies and the Politics of Permanent Crisis, 1979-1999. Cambridge: Cambridge University Press.

Wildlife Sector Review Task Force (WSRTF) (1995) A Review of the Wildlife Sector in Tanzania. Volume 1: Assessment of the Current Situation. Dar es Salaam: Ministry of Tourism, Natural Resources and Environment.

The World Bank (2006) 2006 World Development Indicators. Washington, DC: The World Bank.

Fred Nelson has worked on a range of field projects and policy processes related to community-based natural resource management, primarily in 
Tanzania, since 1998. He is currently the director of Maliasili Initiatives, PO Box 8372, Arusha, Tanzania; e-mail: fnelson@habari.co.tz.

Arun Agrawal teaches and carries out research as a Professor of Environmental Studies at the University of Michigan's School of Natural Resources and Environment, Dana Building, 440 Church Street, Ann Arbor, MI 481091041, USA. He has published on environmental governance of pasturelands, forests, and wildlife, with a focus on livelihoods, biodiversity, and climate change. His work has appeared earlier in Conservation Biology, Development and Change, Proceedings of the National Academy of Sciences, Science, and World Development. 